\title{
I \\ forplantningens \\ tegn
}

\section{Af Christine Glensted}

Forplantningen som biologisk vilkair spiller en afgorende rolle for relationen mellem konnene. Dette kommer til udtryk op gennem bele den vestlige kulturhistorie, hvor kvinden ofte defineres ved moderskabet. En analyse af disse forplantningsfantasievs betydning for representationen af de to $k ø n$ i to udvalgte noveller af Heinrich von Kleist og Thomas Mann og $i$ nutidige diskurser om fertilitetsteknologi kaster lys over ubevidste tankefigurer.

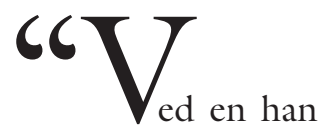

[male animal] forstår vi en, der forplanter sig $\mathrm{i}$ en anden, ved en hun [female] forstår vi en, der forplanter sig i sig selv" (Aristoteles 1942, 716). Med denne definition af kønsforskellen indskriver Aristoteles sig som en af de første i en vestlig tradition for at sammentænke køn og forplantning. Han foretager her en afgørende tolkning af forplantningsvilkåret ved eksklusivt at fokusere på spørgsmålet om lokalitet og på det forhold, at kvindekroppen udgør forplantningens fysiske sted. Dette er helt i tråd med en fundamental tendens i den vestlige filosofi til at forskyde en grundlæggende modsætning mellem ånd og krop til en modsætning mellem kønnene. Dette gør det muligt for den mandlige filosof at opfatte sin tænkende bevidsthed som sin egentlige væren og abstrahere fra den fysiske krop, der selv efter klipningen af navlestrengen forbinder ham med et kvindeligt ophav. Denne fortrængningsprægede mandlige begrebsliggørelse af kønsforskellen og for- 
plantningen gør kvindekroppen, eller nærmere moderkroppen, til en størrelse, som det for manden gxlder om at kontrollere. Den patriarkalske samfundsstruktur kan netop forstås som en sådan kontrolforanstaltning: Det er manden som patriark, som fader, der her etableres som magthaver.

Denne fantasi om magt over forplantningen synes at manifestere sig overalt i den vestlige kanons repræsentationer af køn. Tit er det de tekster, som ikke er direkte beskxftiget med svangerskab og forplantning, der leverer de mest sigende vidnesbyrder om denne fantasi. Jeg vil i det følgende vende mig mod to kanoniserede tyske noveller, som egentlig 'handler om' henholdsvis krig og vold og sygdom og død, men som samtidig udfolder radikale patriarkalske tolkninger af forplantningen som vilkår. Det drejer sig om Heinrich von Kleists "Die Marquise von O..." fra 1808 og Thomas Manns "Die Betrogene" fra 1953. Ved at analysere tekster med en vis tidslig afstand ønsker jeg at påvise bestemte forplantningsfantasiers kontinuitet. De valgte tekster er repræsentative indslag i en kønstænkning med spor tilbage til Aristoteles. Kontinuiteten vil jeg slutteligt understrege ved at perspektivere til aktuelle etiske diskussioner om forplantningsteknologiens potentialer: Også disse bærer nemlig præg af at være indlejret $i$ en tradition præget af maskuline fantasier om kontrol over forplantningen. Det er artiklens væsentligste pointe, at vores forståelse af køn er snævert forbundet med forståelsen af forplantningen. Vi er tilbøjelige til at tænke forskellen på mand og kvinde som modsætningen mellem far (som bidrager på afstand) og mor (hvis hele krop er involveret). Op gennem den vestlige kulturhistorie flyder repræsentationen af (den ideelle) kvinde og moderen sammen i en tankefigur, der gør det vanskeligt overhovedet at tenke kønsforskellen hinsides forplantningen.

Den følgende analyse hviler på en kønsopfattelse, der tager udgangspunkt i den kropslige erfaring af kønsforskellen som et fundamentalt, materielt vilkår. Dertil kommer imidlertid en lige så fundamental fantasi om denne forskels betydning: En fantasi som næres af både den reelle anatomiske erfaring og de kulturelle udlægninger, som vi konfronteres med (i litteraturen såvel som i videnskaben). Forskellen mellem mand og kvinde vil således altid allerede være indspundet $\mathrm{i}$ et lag af symbolisering og kulturel kodning. ${ }^{1}$ Den følgende analyse følger sporene af denne kodning ved at afdække de 'fortællinger' om køn og forplantning, som udfolder sig i novellernes retorik sideløbende med de 'egentlige' handlinger.

\section{FORPLANTNINGSFORTÆLLINGEN I Thomas Manns "Die Betrogene"}

Manns novelle er centreret om Rosalie, som lever en fredsommelig enketilværelse i 1920'ernes Düsseldorf, indtil hun bliver offer for det bedrag, som novellens titel henviser til. Bedraget består i, at blødninger, som i virkeligheden skyldes en ondartet kræftsygdom, for den aldrende kvinde fremstår som genvunden frugtbarhed. Bedraget gennemsyrer hele tekstens retorik, for så vidt som selve sygdommen ikke blot befinder sig i livmoderen, men også eksplicit metaforiseres som en form for afkom af den læge, der ved novellens slutning bringer den til verden:

Ser De, jeg benægter ikke, at livmoderen selv producerer det $x$ dende afkom [das Freß-

gezücht]. Og dog råder jeg Dem til at overtage min formodning om, at hele redeligheden har sit udspring i æggestokkene - i ubenyttede granuløse celler, der indimellem hviler dér fra fødslen og efter overgangsalderen udvikler sig ondartet gennem Gud ved hvilken pirrende hændelse (Mann 1993, 469). ${ }^{2}$

Lægens henvisning til en udløsende pirring antyder, at der mellem det angivelige frugtbarhedsunder og 'afkommets forløsning' er indtruffet en form for befrugtning. Dette 
peger tilbage på den unge huslærer Ken Keaton: Den midaldrende kvindes kropslige forandringer er fra begyndelsen akkompagneret af hendes tiltagende forelskelse $i$ Ken. En nærlæsning af teksten bekræfter denne sammenkædning af erotisk betagelse og patologisk udvikling, idet Ken synes at have en finger, eller nærmere en hånd, med i spillet, hvad angår den tilbagevendte frugtbarhed. Under en middag forud for underets indtræffen udbreder han sig således om smakpåsken - et folkeligt europæisk frugtbarhedsritual, som han finder fascinerende. Umiddelbart forud for hans beskrivelse af unge mænd, der slår piger og afgrøder med friske birkeris for at stimulere deres frugtsommelighed, har Ken forklaret, hvordan han, for at skåne sine fine hænder, altid bar handsker, da han engang arbejdede som gartner. Teksten foretager altså her en metonymisk manøvre, der behændigt får anbragt frugtbarhedsritualets livris i Kens behandskede hænder.

$\mathrm{Ud}$ over denne diskrete, associative iscenesættelse af Ken som frugtbarhedsindpisker udspiller der sig mod slutningen af novellen en udveksling mellem Rosalie og Ken, som på tekstens metaforiske plan antyder en form for befrugtning. Under en udflugt til et gammelt slot synger Rosalie en kærlighedserklæring til vinden, som peger tilbage på hendes tidligere lovprisning af vindbestøvningen - en forplantningsteknik hun finder særligt bedårende. Mens hun synger får hun øje på Kens lommetørklæde:

Lommetørklædet hang langt ud af hans brystlomme, og med en pludselig drejning og vidt åbne øjne stoppede Rosalie det dybt ned i lommen på ham. »Anstændighed, anstændighed, unge mand! « sagde hun med ærbar, misvisende hovedrysten (Mann 1993, 459).

Rosalie har tidligere fremhævet netop lommetørklædet som tegn og med begejstring understreget, hvordan de unge som udtryk for sædernes opblødning lader det hænge:
"Som en fane lader de det hænge ud, det halve lommetørklæde (...)" (Mann 1993, 448). Kens lommetørklæde udgør netop en sådan oprørsk fane, men det besidder derudover en metaforisk værdi, der forstærker betydningen, da det netop som lommetørklæde kommunikerer med Rosalies mest insisterende kropsdel: Hendes næse. Novellen igennem tiltrækker denne evindeligt rødmende legemsdel sig påfaldende opmærksomhed. Den blodtilførte næse med dens iøjnefaldende fallostræk gør sig især bemærket ved Rosalies ihærdige, men forgæves forsøg på at overpudre den forud for Kens besøg. Det er til denne begærsignalerende næse, Kens lommetørklæde tilbyder sig.

Under den efterfølgende svanefodring finder der en iøjnefaldende udveksling sted mellem Ken og Rosalie i form af det brød, som egentlig er tiltænkt fuglene. Ken opbevarer brødet $i$ en af sine lommer, og det er derfor lunt efter den tætte kontakt med hans krop. At episoden repræsenterer et kropsligt møde mellem Ken og Rosalie antydes af, at der er tale om netop brød, hvis ultimative status som metafor for kroppen, nadveren som bekendt opretholder. Når Rosalie indtager brødet, kan det derfor med vindbestøvningens insemination-perstedfortreder som kontekst - udlægges som en metafor for den befrugtning, der forudsættes af lægens efterfølgende udlægning af kræftcellerne som et ondartet afkom.

Samme nat hjemsøges Rosalie af endnu en blødning fra sit underliv. Denne gang udelukker mængden af blod dog, at der er tale om genvunden frugtbarhed, hvorfor Rosalie underkastes føromtalte kirurgiske indgreb, som bringer det patologiske afkom til verden. Rosalie har således ved novellens afslutning lagt krop til en fuldt afrundet forplantningsfortælling, som sideløbende med realplanets sygdomshistorie udspiller sig på tekstens metaforiske plan: Fra frugtbarhedens indstiftelse over den inseminerende påvirkning til den afsluttende forløsning. 


\section{FORPLANTNINGEN OG DEN VIDENSMÆSSIGE ULIGHED}

En lignende forplantningsfantasi udspiller sig i Heinrich von Kleists "Die Marquise von $\mathrm{O}$..." fra 1808, hvor den manifesterer sig i selve den centrale intrige, der kan anskues som den mandlige hovedfigurs forsøg på at udligne en særlig kønsmæssig ulighed ved forplantningen, nemlig den, der udspringer af kønnenes forskellige grader af viden. Novellen begynder med meddelelsen om, at markisen i de lokale aviser bekendtgør, at hun - uden at vide hvordan - er kommet i omstændigheder og derfor beder faderen til det barn, hun venter, om at melde sig. Derefter oprulles de forudgående begivenheder, nemlig russernes invasion af markisens familieresidens under en unavngiven krig samt den krænkelse, markisen i den anledning bliver offer for. Betegnelsen voldtægt synes ikke at være dækkende, for så vidt som markisen angiveligt er bevidstløs under selve overgrebet og efterfølgende ikke er klar over, hvad hun har været genstand for. Tværtimod betragter hun gerningsmanden grev $\mathrm{F}$ som sin redningsmand. Intrigen hviler altså på den kvindelige figurs manglende evne til at tyde sin krops tegn. Markisen har ingen grund til at tro, at hun er gravid og tillægger derfor ikke de symptomer, hun fra begyndelsen genkender som svangerskabssymptomer, nogen betydning.

Hvis forplantningen som gåde antages at udgøre et fundamentalt menneskeligt vilkår, som på grund af den fastlagte rollefordeling etablerer en kønsmæssig ulighed, bliver den omtolkning af rollefordelingen, der er på spil i "Die Marquise von O...", pludselig påfaldende. Kvindekroppens ultimative gåde, livmoderens indhold, er således for manden ikke kun relateret til de imaginære fantasier om hans egen oprindelse, men også mere pragmatisk et spørgsmål om reproduktion. Hvor moderens status som mor er givet, er faderens status som far aldrig helt sikker. Netop dette mandlige eksistensvilkår synes "Die Marquise von O..." at manipulere med: Det handler ikke bare om kontrollen over den kvindelige livmoder, men mere specifikt om mandens overtagelse af en eksklusiv erkendelsesmæssig position som forplantningsrelationens $v i$ dende part. Greven får med vold og magt vendt den vidensmæssige ulighed, som præger selve forplantningsrelationen, hvorved han på sit køns vegne får tilfredsstillet et andet og måske endnu mere fundamentalt behov end det seksuelle.

Som markisen må også Rosalie se sig reduceret til menig tegntyder i relationen til sin egen krop, hvilket står i skærende kontrast til det skarpsyn, hvormed hun angiveligt er i stand til at aflæse andre kvinders kropslige tegn. Det understreges således allerede ved novellens begyndelse, at Rosalie er usædvanligt observant over for de signaler, der er forbundet med kvindekroppens særlige erfaringer (Mann 1993, 403). Denne angivelige sensibilitet over for kvindekroppens fysiologiske forandringer antager i lyset af tekstens slutning et ironisk skær, idet der tilvejebringes en total vidensmæssig omvending: Rosalie viser sig ikke at have øje for, hvad der foregår i hendes egen livmoder. Modsat den mandlige lægestand, under hvis udforskning af Rosalies underliv det endda understreges, at den patologiske udvikling er synlig "selv for det blotte øje" (Mann 1993, 469).

I begge noveller er kvinderne altså reduceret til forplantningssituationens objekt: Markisens krop er genstand for grevens uigennemskuelige manipulationer og Rosalies for selve tekstens retoriske forplantningsfortælling, som făr hende til at fejltolke sin krop til døde. Kvindekroppens gåde vendes mod kvinden selv, og teksterne kan således læses som en slags diskursive kompensationer for den ulighed, som forplantningen som vilkår etablerer kønnene imellem.

\section{Menstruationen SOM TEGN OG KVINDEN SOM KROP}

Markisens uvidenhed og dermed intrigens 
opretholdelse hviler hos Kleist på novellens ejendommelige udeladelse af den fysiologiske funktion, der normalt optræder som kvindens epistemologiske allierede, når spørgsmålet om svangerskab skal afgøres. Kun ved at forholde sig fuldstændig tavs over for menstruationen som fænomen kan teksten opretholde markisens forvirring adskillige uger efter befrugtningen. Markisen berøves den ene kropslige funktion, som ville have kunnet hjælpe hende til tidligere at tyde den "mærkelige tilstand" (Kleist 1993, 109), som hendes krop befinder sig i.

Intrigen hviler altså $\mathrm{i}$ "Die Marquise von O..." på fraværet af det tegn, som den udeblevne menstruation udgør. I "Die Betrogene" er selve menstruationen faktisk fraværende, men den er i høj grad til stede som tegn, idet Rosalies fejltolkning af sit blødende underliv udgør et afgørende element $\mathrm{i}$ iscenesættelsen af novellen som forplantningsfortælling. Mest iøjnefaldende bliver hele denne tegntolkningspraksis, når Rosalie insisterer på at meddele sit angivelige frugtbarhedsunder til datteren gennem nøje iscenesatte kropslige signaler. Datteren bliver således bedt om at indfinde sig i moderens soveværelse, hvor hun konfronteres med en hvilende, svagelig Rosalie:

Hun nikkede til den indtrampende datter med et smil præget af affekteret mathed, sagde dog intet, men lod datteren spørge:

"Hvad er der i vejen Mama? Du er vel ikke syg?” “Åh nej, mit barn, vær ikke urolig, det er ingen sygdom. Jeg var meget fristet til selv at gå over og hilse på dig frem for at lade dig tilkalde. Men jeg er nødt til at skåne mig, er henvist til at holde mig i ro, som vi kvinder indimellem er det.” (Mann 1993, 442)

Rosalie iscenesætter sig som menstruerende kvinde og bringer hele sin fremtræeden $\mathrm{i}$ overensstemmelse med sin egen tolkning af sit på ny blødende underliv. Hun positionerer sig som en gådefuld masse ladet med betydning. Det bemærkelsesværdige ved
Rosalies omgang med menstruationsmetaforikken er imidlertid, at relationen mellem tegn og betegnet også for hende selv synes at være temmelig ustabil. Rosalie bekender sig således udelukkende til blodets metaforiske betydning, som under hendes optik primært udgøres af dets sanktionering af kvindens erotiske duelighed og dermed af hendes forbindelse til Ken. Menstruationsblodets faktiske, bogstavelige betydning, nemlig kvindens potentielle moderskab, er for hende lige så fraværende som den patologiske udvikling, blodet i hendes tilfælde er tegn på.

Afgørende er det, at der er tale om strømme, som er uden for Rosalies kontrol, og måske endda uden for tekstens kontrol. Dette antydes af strømmenes stadige tilbagevenden. Først i Rosalies bevidsthed: “Nu bliver mit indre ved tanken om hans vækkende risning overstrømmet, overskyllet af skamfuld sødme" (Mann 1993, 422), siden i fortællerens diskurs: “(...) og igen følte hun sit indre blive overstrømmet overskyllet, af uhyrlig sødme.” (Mann 1993, 430) og slutteligt i lægernes medicinske udlægning: "Så bliver organismen, post festum, om De vil, overvældet, overstrømmet, overskyllet af østrogenhormoner." (Mann 1993, 470) Ordvalget er overalt det samme, hvilket antyder, at fornemmelsen af blodets ukontrollerbare strøm er selve tekstens. Den tvangsmæssige fascination, der synes at være forbundet med denne strøm, manifesterer sig i den overflødige brug af synonymer for den strømmende væske: Selve sproget bliver nærmest overstrømmende i sit forsøg på at indfange og prxcisere fornemmelsen.

Den uhyrlige sødme afdækkes under lægernes optik som østrogenhormoner, hvilket ligner et forsøg på at sætte en stopper for den udefinerbare strøm af kropsvæsker ved at identificere den som et utvetydigt kvindeligt fænomen. Den ukontrollerbare, lækkende væske bliver så at sige diskursivt indkapslet i kvindekroppen i kraft af en sproglig betegnelse, som gør Rosalies 
patologiske blødninger til kønnede blødninger på linje med menstruationen. Det interessante er, at netop mens lægen diskursivt bekender sig til denne konventionelle patriarkalske tankefigur, der tænker kvindekroppen som en krop, der går over sine bredder, forrådes han selv af en kropslig grænseoverskridelse: Det bemærkes, at der i hans "vandblå øjne let stod tårer, uden at det havde det mindste med bevægelse at gøre." (Mann 1993, 469). Under undersøgelsen af Rosalie brydes selve lægens monolog tekstligt af netop disse tårer: “(...) tilføjede han, med øjnene fulde af tårer, som ikke havde nogen betydning, (...)" (ibid.). Dén videnskabelige kolonisering af Rosalies underliv, som lægens belæring synes at udgøre, ledsages altså tekstligt af henvisninger til lægens egen krop, hvis tegn dog hævdes at være uden betydning. Netop den gentagne insisteren på tårernes manglende betydning skaber en bemærkelsesværdig modsætning mellem lægens krop og Rosalies i overensstemmelse med det kønsmæssige dige, lægen forsøger at etablere mod væskestrømmen ved at henvise til østrogenerne. Det kendetegnende ved Rosalies blødninger er netop deres betydningsfuldhed, deres henvisningsevne, som endda peger ud over lægens medicinske betydningsunivers og får ham til at henvise til en ukendt pirring som celleudviklingens og dermed blødningernes gådefulde oprindelse. Kvindekroppens væskestrømme antages altså at udsige noget om det subjekt, som kroppen huser, hvorved forestillingen om et uoverstigeligt skel mellem krop og bevidsthed pludselig er truet. Det kan forklare lægens behov for insisterende at markere et skel mellem kønnene og dermed opretholde forestillingen om sit eget intellekts uafhængighed af materien.

\section{UNDFANGELSEN SOM UDFYLDNING}

Som kønnet væske udgør menstruationsblodet den kvindelige pendant til mandens sæd: Begge væsker bidrager som bekendt til forplantningen, men med den afgørende forskel, at kun mandens væske manifesterer sig i selve undfangelsessituationen som tegn på erotisk nydelse. Denne forskel făr for Aristoteles undfangelsen og gåden om den kvindelige nydelse til at flyde sammen i en for kvinden særdeles ufrugtbar tankefigur:

Her er en indikation af, at kvinden ikke udskiller sæd af samme art som manden, og at afkommet ikke formes af en blanding af to typer sæd, hvilket nogen hævder. Meget ofte nedkommer kvinden, selvom hun ikke har opnået nogen nydelse ved samlejet, mens hun modsat ofte ikke bliver svanger, hvis hun opnår lige så meget nydelse som manden, og de begge holder samme tempo. (Aristoteles, 1942, 97).

Argumentationen hviler her på opfattelsen af sæden som en væske, der indikerer nydelse, hvorved Aristoteles kan udlede kvindens manglende sædproduktion fra det faktum, at kvindens nydelse ikke er nødvendig for undfangelsen. Et faktum, som i den afsluttende bemærkning ender $i$ antydningen af, at den kvindelige nydelse faktisk synes at modvirke forplantningen. Under denne optik bliver kvindens erotiske nydelse en trussel, som effektivt må imødegås af den mand, som ønsker at formere sig, hvilket netop synes at lykkes for greven i "Die Marquise von O...”. Markisens erotiske nydelse er tekstligt så fraværende, at det faktisk ikke lader sig afgøre, om den er fortrængt, bortcensureret eller aldrig har været der. Selve mødet mellem greven og markisen skildres nemlig ikke i teksten, i stedet figurerer en efterhånden berømt tankestreg:

Han [greven] (...) bød derefter med nogle forbindtlige franske vendinger damen sin arm og førte hende, der efter disse optrin var ganske stum, over i slottets anden, af flammerne endnu uberørte, fløj, hvor hun fuldstændig bevidstløs sank sammen. Her - traf han, da hendes forskrækkede tjenestepiger kort efter dukkede op, anstalter til at tilkalde en læge; 
forsikrede i det han tog sin hat på, at hun snart ville komme sig igen, og vendte tilbage til kampen (Kleist, 106).

Spørgsmålet om, hvad tankestregen dækker over, har i novellens receptionshistorie udkrystalliseret sig som læsningernes centrale omdrejningspunkt. At der finder en undfangelse sted er med det efterfølgende svangerskab hævet over enhver tvivl, men selve repræsentationen $i$ form af tankestregen er interessant. Denne fungerer naturligvis som det lingvistiske tegn for udeladelse, men ud over denne referentielle tegnværdi er tankestregens ortografiske udseende bemærkelsesværdig. Der er tale om en stav, som nok er det tretteste, det latinske alfabet og det dertilhørende tegnsystem kommer på en fallos. Dér, hvor det erotiske møde mellem kønnene er fraværende i teksten - og hvor grevens køn altså er udeladt - optræder i teksten en ortografisk markering, som deler dette køns fremtræden. Hvis staven sættes i relation til tekstens andet markante grafiske symbol - nemlig det O, der udgør det tekstlige tegn for markisen - ligner det pludselig et særegent repræsentationsforsøg. Måske forsøger teksten her at udnytte de lingvistiske tegns form, deres fysiske fremtræden, frem for deres referentialitet? I så fald udgør staven og hullet en klassisk, stiliseret afbildning af de menneskelige kønsorganer - og tegnenes forening en håndgribelig, geometrisk representation af undfangelsen. En visuel representation, som hviler tungt på forestillingen om kvinden som mandens sted: O'et betegner markisen som en tom skal, der venter på at blive udfyldt, først af greven og siden af fostret. Dette er i overensstemmelse med den ovennævnte tolkning af kvindekroppen som forplantningens sted. Novellens visuelle repræsentation af undfangelsen kan dermed forbindes med de maskuline fantasier om kontrol over forplantningen.

\section{FORPLANTNINGEN SOM}

SEKSUALITETENS ENESTE MÅL

Denne udfyldning som mål for relationen mellem mand og kvinde er blevet kritiseret af den franske filosof Luce Irigaray, blandt andet $\mathrm{i}$ hendes analyse af Platons Symposium, som fokuserer på Diotimas tale om kxrligheden (Irigaray 1977). Talen udlægger eros som en evig stræben efter forening, der bestandigt udfolder sig mellem de elskende og ikke består i deres endegyldige sammensmeltning. Denne definition af Eros fremstår for Irigaray som et ideelt emblem for relationen mellem kønnene, men som Diotimas tale skrider frem, bevæger den sig fra selve relationen til dens årsag, som Diotima søger uden for relationen selv. Hun ender med at lokalisere den i relationens resultat, hvorved forplantningen som fænomen pludselig gør sin entre, hvilket Irigaray diagnosticerer som en art tankens forlis. Efter introduktionen af forplantningen som telos eller endemål, indfører Diotima sondringen mellem åndelige og kødelige svangerskaber, hvorved relationen på tværs af kønnene bliver en laverestående version af den åndeligt udviklende relation mellem mænd. Og herfra, konstaterer Irigaray, er der ingen vej tilbage: "Vores efterfølgende tradition har tilmed lært os, at det er forbudt eller nyttesløst at være elskende medmindre, der er forplantning." (Irigaray 1984, 30)

Det er præcis denne tradition, jeg i min analyse har indskrevet Kleist og Mann i. Interessant er i denne forbindelse de refleksioner, som Kleists markise gør sig over sit kommende barns særlige status: Barnets hemmelighedsfulde oprindelse forekommer hende således "mere guddommelig end andre menneskers." (Kleist 1993, 126) Guddommeligheden synes specifikt at bestå i fravaret af en seksuel relation: Mens greven på sin side udlever en fantasi om total kontrol over forplantningen, forfalder markisen til fantasier om den ubesmittede undfangelse. I begge tilfælde er der tale om fantasier, der overvurderer forplantningen som den 
seksuelle relations endemål. Samme prioritering præger selve novellens komposition, hvor det seksuelle møde mellem kønnene også tekstligt udelades.

Noget lignende gør sig gxldende hos Mann: Den metaforiske forplantningsfortælling, som jeg i det foregående har udledt af novellen, synes, som den tradition Irigaray henviser til, at insistere på, at hvor der er begær, skal der være forplantning. I den midaldrende Rosalies tilfælde er begæret ude af trit med denne teloslogik og afkommet bliver derfor af patologisk art. Under denne optik fremtræder Rosalies sygdom altså som en straf for hendes, i ordets egentlige betydning, perverse begær. ${ }^{3}$

\section{FORPLANTNINGSTEKNOLOGIENS RETORIK}

Det har i det foregående handlet om, hvordan forplantningen som vilkår betinger vores forståelse af kønsforskellen. Under denne optik står det klart, at de forandringer, som ad teknologisk vej bliver forplantningen til del, vil kunne revolutionere relationen mellem kønnene. Amadeo F. D'Adamo og Elaine Hoffmann Baruch har med dette for $\varnothing j$ je foretaget en pragmatisk analyse af de nye teknologiers risikoer og potentialer. De hæfter sig især ved disses udligning af eldningens ulighed, som bunder i, at kvindens reproduktive år er væsentligt færre end mandens. Ved at få nedfrosset enten $x g$ eller embryo 4 bliver det muligt for kvinden at udskyde sit svangerskab, for så vidt som livmoderen også efter frugtbarhedens ophør er fuldt fungerende. D'Adamo og Baruch bemærker, at det kan ændre betingelserne for partnervalget ved at ligestille relationen mellem en ældre kvinde og en yngre mand med den modsatte konstellation. Samme teknologi tillader, at det fysiske moderskab fordeles på to kvinder, som stiller henholdsvis $x g$ og livmoder til rådighed. D’Adamo og Baruch er ikke blinde for den udbytning, som dette muliggør. Men de viser, at argumenterne mod brugen af rugemødre, som handler om risikoen for udbytning, ofte er baseret på forudsætningen om, at moderskab bør koste opofrelse, det vil sige, at den kvinde, som ikke selv vil lægge livmoder til, ikke har fortjent et barn. ${ }^{5}$

Det er imidlertid bemærkelsesværdigt, at selv D'Adamos og Baruchs kontrast til, hvad de udpeger som traditionelle kønsforestillinger, bærer præg af at være indlejret i samme tradition: Deres visioner udgør en lighedsutopi, hvor idealet bliver at tilnærme kvindens betingelser mandens. Det ultimative emblem på denne utopi er den kunstige livmoder, som mand og kvinde på lige fod forsyner med sæd og xg. De mulige forandringer $\mathrm{i}$ forplantningssituationen bliver med denne utopi ikke anledning til en gentænkning af kønsforskellen, men giver snarere næring til fantasien om at komme binsides kønnet - og hinsides den anden, for så vidt som en af teknologiens eftertragtede muligheder er enlige forældreskaber, hvilket synes at åbenbare en fantasi om at indtage begge kønsmæssige positioner. Dette nærmer sig fundamentale patriarkalske mytologier, hvor for eksempel Athena fostres bag Zeus pande, eller hvor faustmytens homunculus undfanges i videnskabsmandens kolbe befriet for både kvindelig og kødelig indblanding.

I dansk sammenhæng garderer Etisk Råd sig i sine anbefalinger mod sådanne fremtidsscenarier ved at insistere på en analogi mellem det kunstige og det naturlige. Det kræves af den kunstige befrugtning, at "forløbet i væsentlige henseender er parallelt med en proces der kunne have fundet sted naturligt." Dette făr især betydning for rådets sondring mellem æg- og sæddonation, som går på, at kvinden ikke på naturlig vis kan overføre sine kønsceller til et andet individ. Vi udfører imidlertid mange andre 'overdragelser', som bryder med kroppens naturlige funktioner - blodtransfusionen er det mest oplagte eksempel. Kun hvad forplantningen angår, har henvisningen til tingenes 'naturlige tilstand' opnået status som argument. Denne 'naturlige tilstand' er dog 
altid en tolket størrelse, hvilket fremgår, når rådet argumenterer for en særlig intim relation mellem kvinde og æg:

Æg er i langt højere grad end sæd en del af en kvindes krop og identitet og derfor kan det være problematisk at tillade donation som ofte vil være resultat af pres fra omverden snarere end af en beslutning kvinden selv har truffet (Etisk Råd, 2007).

Det er ikke umiddelbart klart, hvorfor kvindens æg i højere grad end mandens sæd er en del af ikke bare hendes krop, men også hendes identitet, hvilket rådet antager i så udstrakt grad, at det har svært ved at forestille sig, at kvinder frivilligt kan finde på at donere disse identitetsbærende celler. Her er rådet på linje med Manns Rosalie, for hvem selve kvindeligheden lå i frugtbarheden. Hvor mandens sæd uden problemer kan accepteres som noget, der cirkulerer uafhængigt af socialt faderskab, er forestillingen om en kvinde der "spreder sine æg" stadig svær at håndtere.

Den vestlige kulturhistorie synes at være præget af en ubevidst forestilling om, at kvindens primære identitet er moderens og af en fundamental patriarkalsk fantasi om at overtage kontrollen over moderkroppen. Det kommer til udtryk i såvel litterære som videnskabelige diskurser. Det eksklusivt kvindelige svangerskab som biologisk vilkår skaber en ubalance kønnene imellem, som patriarkatet igennem århundreder har forsøgt at kompensere for ved at fremstille kvinden som et stykke biologi, der som den øvrige natur må underlægges patriarkalsk kontrol og kultivering. Irigarays utopi om en forståelse af kønsforskellen, som ikke bunder i forplantningens rollefordeling, synes altså ikke at komme nærmere med forplantningsteknologiens forandringer: Disse er endnu ikke blevet anledning til en gentænkning af kønsforskellen, men blot til en genopførelse af kendte kønsstereotyper i ny forklædning.

\section{Noter}

1. Min teoretiske position er formuleret i forlængelse af Luce Irigarays kønsfilosofi og af litteraturanalytiker Lilian Munk Rösings udlægning og udvikling af denne i Konnets katekismus.

2. Jeg henviser til originalteksterne og bringer citater af Kleist og Mann i egen oversættelse.

3. En mere udfoldet tekstanalyse af de to noveller findes i mit speciale: Forestillinger om kon og forplantning, Københavns Universitet, 2007.

4. Et embryo er et kim eller et foster i den tidlige udviklingsperiode.

5. Se f.eks. analysen af Den britiske Warnock-komites anbefalinger mod brugen af rugemødre, D'Adamo \& Baruch 1986 p. 77.

\section{LITTERATUR}

- Aristoteles (1942): Generation of Animals. Translator: A.L. Peck, Cambridge.

- D’Adamo, Amadeo F og Baruch, Elaine Hoffman (1986): "Wither the womb? Myths, Machines, and Mothers" i Frontiers 1986/1.

. Etisk Råd (2007): "Hvem skal have adgang til kunstig befrugtning" og "Donation af sæd og æg” lokaliseret d. 16.11.2007 på http://www.etiskraad.dk/sw3820.asp, Etisk Råd.

. Goethe, Johan Wolfgang von (1997): Faust.

Taschenbuch, München.

- Irigaray, Luce (1977): Étique de la difference sexuelle. Les Édition de Minuit, Paris.

- Kleist, Heinrich von (1993): Sämtliche Werke und Briefe, Taschenbuch, München

- Mann, Thomas (1993): Sämtliche Erzäblungen in zwei Bänden. S. Fischer Verlag, Germany.

- Platon (1963): Symposion Hans Reitzel, København.

· Rösing, Lilian Munk (2005): Kønnets katekismus. Roskilde Universitetsforlag, Roskilde.

\section{SUMMARY}

The thesis of this article is that our understanding of gender and gender differences is characterised by unacknowledged fantasies related to reproduction as a fundamental condition of buman existence. The article analyses works by Heinrich von Kleist and Thomas Mann with a view to revealing how unconscious masculine ideas connected with 
the conditions of reproduction determine the representation of the two genders. The analysis focuses on the metaphors contained in the literary texts and demonstrates that it is through the rhetoric rather than the explicit messages of these texts that these unconscious $i d e a s$ come to expression. On the basis of these samples from the literary historical canon, the article draws parallels with contemporary ethical and scientific discourses on reproduction technology, and points out that these discourses share fantasies of gender and reproduction with fiction that is 50 or 200 years older.

Christine Glensted, cand.mag. 